\title{
Awareness of Disability Certificate uses among the Caregivers of Persons with Mental Illness
}

\section{Vikas Kumar ${ }^{1}$, Dr. Narendra Kumar Singh ${ }^{2}$}

1. Ph.D. Scholar (PSW), Dept. of Psychiatric Social Work

2. Psychiatric Social Worker, Department of Psychiatric Social Work

Background: There are many benefits for the person with disability such as pension, reservation in various field, free education, insurance, healthcare and rehabilitation etc. The biggest obstacle to approach this benefit is the lack of awareness and poor knowledge of certificate benefits as well lack of knowledge of obtaining the certificate.

Aim: To assess the awareness and uses of disability certificate among the caregivers of persons with mental illness.

Methods: Purposive sampling technique was used for selecting samples. The study was carried out at Ranchi Institute of Neuro Psychiatry and Allied Sciences in Ranchi district. Total number of 160 respondents (caregivers/family member of person with mental illness) were taken in the study. Subjects were evaluated using socio demographic datasheet and self-made questionnaire.

Results: Results indicated that caregivers of the persons with mental illness were not aware about health care facility, social security, insurance facility, rehabilitation provision, reservation for that land allotment, reservation facilities available for developmental scheme, skills development program, marketing facilities.

Conclusion: Finding of the present study concluded that majority of the caregivers of the persons with mental illness have not been aware of the disability certificate and its uses which is provided by the government of India.

Key Words: Disability certificate, caregivers, awareness and usefulness.

\section{INTRODUCTION :}

Disability is a hurting, onerous and special challenge for individuals and their families. ${ }^{[1]}$ The multi-level large scale household epidemiological survey undertaken by NIMHANS, Bengaluru in 2015-16 supported by Ministry of Health and Family Welfare across 12 states of India reported a prevalence rate of mental morbidity of individuals above the age

\section{Address for correspondence :}

Dr. Narendra Kumar Singh (MSW, M.Phil, Ph.D.)

Psychiatric Social Worker, Department of Psychiatric Social Work Central Institute of Psychiatry

Kanke, Ranchi - 834006 of 18 years as $10.6 \%$. The life time prevalence in the surveyed population was $13.7 \% .{ }^{[2]}[11]$ As per Census 2011, in India, out of the $121 \mathrm{Cr}$ population, about $2.68 \mathrm{Cr}$ persons are 'disabled' which is $2.21 \%$ of the total population. A third of the global burden of disease for mental, neurological, and substance use disorders occurs in India and China, which is more than in all high-income countries combined ${ }^{[3]}$. The burden of these disorders is estimated to increase by 23\% in India, between 2013 and 2025. ${ }^{[3]}$

According to Global Burden of Disease Substance use and mental disorders accounted for $7.4 \%$ of all 
disability-adjusted life years (DALYs) and were the leading cause of years lived with disability worldwide in 2010. ${ }^{[4]}$ Herein, depressive disorders accounted highest $(40.5 \%)$ in DALYs while schizophrenia $(7.4 \%)$ and bipolar affective disorder (BPAD) $(7.0 \%)$ also contributed ${ }^{[4]}$, and these disorders have severe negative consequences on academic, occupational, social, and family functioning of the patients. ${ }^{[5]}$ This situation becomes worse with regard to providing care and social welfare measures to persons with mental illness in the low- and middle-income countries. $^{[6]}$ It was found that mental disorders are associated with a similar or higher negative impact on daily functioning than arthritis and heart

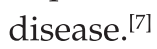

The Rights of Persons with Disabilities Act, 2016 replaced the Persons with Disabilities Act, 1995 to comply with the United Nations Contract on the Rights of Persons with Disabilities. Whereas the United Nations General Assembly adopted its Convention on the Rights of Persons with Disabilities on the 13th day of December, 2006, PWD Act 2016 covers progressive changes, there were number of needs and right of people with disability in mental illness. ${ }^{[8][9]}$

The Act 1995 listed seven conditions of disabilities, which were blindness, low vision, leprosy cured, hearing impairment, locomotors disability, mental retardation, and mental illness. The 2016 Act expanded the list to include 21 disabilities stating that, "person with disability means a person with long-term physical, mental, intellectual or sensory impairment which, in interaction with barriers, hinders his full and effective participation in society equally with others." Expanded disability includes cerebral palsy, dwarfism, and muscular dystrophy, acid attack victims, hard of hearing, speech and language disability, specific learning disabilities, autism spectrum disorders, chronic neurological disorders such as multiple sclerosis and Parkinson's disease, blood disorders, and multiple disabilities. According to PWD Act 2016, mental illness is a substantial disorder of thinking, mood, perception, orientation, or memory that grossly impairs judgment, behavior, and capacity to recognize reality or ability to meet the ordinary demands of life but does not include retardation which is a condition of arrested or incomplete development of mind of a person, especially characterized by subnormality of intelligence." The act makes special provisions for "persons with benchmark disabilities", who are defined as those with at least $40 \%$ of any of the above disability. PWD having high support needs are those who are certified as such under section $58(2)$ of the Act. ${ }^{[8][9][12]}$

According to PWD act 2016 "the appropriate Government shall ensure that the persons with disabilities enjoy the right to equality, life with dignity and respect for his or her integrity equally with others. Government ensure that no person with disability shall be discriminated on the ground of disability, unless it is shown that the impugned act or omission is a proportionate means of achieving a real aim and no person shall be deprived of his or her personal liberty only on the ground of disability. The appropriate Government also takes necessary steps to ensure reasonable accommodation for persons with disabilities. ${ }^{[8] 12]}$ Government of India provision of "Unique ID for Persons with Disabilities" project is being implemented with a view of creating a National Database for PwDs, and to issue a Unique Disability Identity Card to each person with disabilities. ${ }^{[10]}$

The Act provides for the access to inclusive education, vocational training, and self-employment of disabled persons without discrimination and buildings, Equal opportunity policy, Social security, Healthcare facilities, Rehabilitation, insurance schemes and various facilities are to be made accessible to the PWD and their special needs are to be addressed. Necessary schemes and programs to safeguard and promote the PWD for living in the community are to be launched by the Government. Cultural life, recreation, and sporting activities are also to be taken care of. Free education for children with benchmark disabilities. All Government 
institutions of higher education and those getting aid from the Government are required to reserve at least $5 \%$ of seats for persons with benchmark disabilities. $4 \%$ reservation for persons with benchmark disabilities is to be provided in posts of all Government establishments with differential quotas for different forms of disabilities, 5\% Incentives to employers in private sector. Special employment exchanges for the PWD are to be set up. Awareness and sensitization programs are to be conducted and promoted regarding the PWD. Special schemes and development programs such as $5 \%$ reservation in allotment of agricultural land and housing in all relevant schemes and development programmes, with appropriate priority to women with benchmark disabilities, $5 \%$ reservation in all poverty alleviation and various developmental schemes with priority to women with benchmark disabilities, 5\% reservation in allotment of land on concessional rate, where such land is to be used for the purpose of promoting housing, shelter, setting up of occupation, business, enterprise, recreation centres and production centres. ${ }^{[8][12][14]}$

The Government run mental health services are not available in most of the districts and in about one-third of the districts in the country, there are no mental health services at all. ${ }^{[12]}$ Vast number of PMI (person with mental illness) with high support needs have no support available to them except that of their family members. Persons with severe mental illness are not in a position to be aware of their illness because of the lack of insight and in these situation their families are great asset in providing them care and support. Strong family and social bond that exist in our country are of great help for these PMI. ${ }^{[13]}$ If the importance of family for this purpose is discouraged, persons living with mental illness and intellectual impairments may get abandoned and may be left to roam on the streets. Act provides that any person with benchmark disability, who considers himself to be in need of high support, or any person or organization on his or her behalf, may apply to an authority, to be notified by the appropriate Government, requesting to provide high support.
Disability certificate" is necessary to approach benefits that would be afforded under the Persons with Disabilities Act (2016) in India. Any person with mental illness seeking benefits must obtain a disability certificate from a specified government healthcare provider. However, issuing a disability certificate would serves no purpose if the beneficiaries are unaware about the benefits. The biggest obstacle to approach this benefit is the lack of awareness and poor knowledge of certificate benefits as well lack of knowledge of obtaining the certificate. The present study conducted a survey to identify to awareness of disability certificate uses among the caregivers of persons with mental illness in Indian setting.

\section{OBJECTIVE}

To assess the awareness and uses of disability certificate among the caregivers of persons with mental illness.

\section{METHODS :}

\section{Sample}

The study adopted descriptive research design and sample of the study was taken through a purposive sampling technique. Total numbers of 160 respondents (caregivers/family member of mentally ill) were taken in present the study.

\section{VENUE OF THE STUDY:}

This study was conducted at Out-Patient Department of Ranchi Institute of Neuro-Psychiatry \& Allied Sciences (RINPAS) Kanke, Ranchi. In this study respondents were the primary caregivers of the patient (i.e. the person who taking the responsibility for care of the patient and is a member of the family, and living with patient).

\section{INCLUSION CRITERIA :}

1. Patients diagnosed mental illness as per ICD-10 DCR (1993) 
2. Caregivers of only those patients were interviewed who have been coming to RINPAS for treatment since the last 2 years or more.

3. Care giver giving written consent for being part of the study

\section{EXCLUSION CRITERIA :}

1. Patients who are not attending with caregiver or family members.

2. Patients attending first time in RINPAS OPD.

\section{STUDY TOOLS :}

a. Socio demographic and clinical

Table 1 : Socio demographic data

\begin{tabular}{|c|l|c|c|}
\hline $\begin{array}{c}\text { S. } \\
\text { No. }\end{array}$ & \multicolumn{2}{|c|}{ VARIABLE } & $\begin{array}{c}\text { Mean } \pm \text { SD } \\
(\mathbf{N}=160)\end{array}$ \\
\hline 1. & Age (In year) & $35.46 \pm 12.75$ \\
\hline 2. & Duration of illness (In year) & $6.98 \pm 4.25$ \\
\hline \multirow{2}{*}{3.} & $\begin{array}{l}\text { Family income } \\
\text { status (In \%) }\end{array}$ & Less than 5000 & $18.33 \%$ \\
\cline { 3 - 4 } & & $5000-10000$ & $50 \%$ \\
\cline { 3 - 4 } & & $10000-15000$ & $20 \%$ \\
\hline \multirow{2}{*}{3.} & Domicile (In \%) & Above 15000 & $1.4 \%$ \\
\hline \multirow{2}{*}{4.} & \multirow{2}{*}{$\begin{array}{l}\text { Education } \\
\text { (caregivers) (In \%) }\end{array}$} & Rural & $76.66 \%$ \\
\cline { 3 - 4 } & & Urban & $26.66 \%$ \\
\cline { 3 - 4 } & & Illiterate & $23.33 \%$ \\
\cline { 3 - 4 } & & Primary & $36.66 \%$ \\
\hline
\end{tabular}

data sheet was prepared by

was $6.98 \pm 4.25$ years. Majority of the patients belonged to rural background and most of the patient's family income was 5000 to $10000.36 .66 \%$ caregivers of persons with mental illness were educated up to primary and $23.33 \%$ caregivers were illiterate.

Table 2 shows that $88.75 \%$ caregivers of persons with mental illness do not know that mental illness comes under the disability and only $47.5 \%$ caregiver know that certificate is provided to the person with mental

\section{PROCEDURE :}

Recruitment of the caregivers, who attended out-patient department (OPD) of RINPAS during study period and fulfilled the inclusion and exclusion criteria. After that a detailed explanation was given to the participants about the purpose of the study and then signed consent form to the participants. Then the socio-demographic \& clinical data sheet and Semi structured interview schedule was applied on the caregivers of patients with mental illness.

\section{RESULTS}

Table 1 shows that mean age of patients was $35.46 \pm 12.75$ and duration of illness
Table 2 - Awareness regarding disability certificate

\begin{tabular}{|c|c|c|c|c|}
\hline \multirow{2}{*}{$\begin{array}{l}\text { S. } \\
\text { No. }\end{array}$} & \multirow{2}{*}{ DOMAIN } & \multicolumn{3}{|c|}{$\mathbf{N}=160$} \\
\hline & & \multicolumn{2}{|c|}{$\mathbf{N}$} & $\%$ \\
\hline \multirow[t]{2}{*}{1.} & \multirow{2}{*}{$\begin{array}{l}\text { Do you know that mental illness come } \\
\text { under the disability/differently abled? }\end{array}$} & Yes & 18 & 11.25 \\
\hline & & No & 142 & 88.75 \\
\hline \multirow[t]{2}{*}{2.} & \multirow{2}{*}{$\begin{array}{l}\text { Is any certificate provided to person with } \\
\text { mental illness? }\end{array}$} & Yes & 76 & 47.5 \\
\hline & & No & 84 & 52.5 \\
\hline \multirow[t]{2}{*}{3.} & \multirow{2}{*}{$\begin{array}{l}\text { Do you know, where you will get this kind } \\
\text { of certificate? }\end{array}$} & Yes & 69 & 43.12 \\
\hline & & No & 91 & 56.88 \\
\hline \multirow[t]{2}{*}{4.} & \multirow{2}{*}{$\begin{array}{l}\text { Do you know what criteria of such certificate } \\
\text { is? }\end{array}$} & Yes & 21 & 13.12 \\
\hline & & No & 139 & 86.88 \\
\hline \multirow[t]{2}{*}{5.} & \multirow{2}{*}{$\begin{array}{l}\text { Have you get disability certificate for you } \\
\text { patient? }\end{array}$} & Yes & 18 & 11.25 \\
\hline & & No & 142 & 88.75 \\
\hline \multirow[t]{2}{*}{7.} & \multirow{2}{*}{$\begin{array}{l}\text { Do you know that government has provided } \\
\text { some facilities for mental disability? }\end{array}$} & Yes & 67 & 41.88 \\
\hline & & No & 93 & 58.12 \\
\hline
\end{tabular}


illness. $66.88 \%$ caregivers do not know that where they can get the certificate and $86.88 \%$ caregivers do not know about criteria for such certificate. Only $11.25 \%$ caregivers got certificate for his patients and only $41.88 \%$ caregivers have knowledge about government facility for mental disability.

Table 3 shows that caregivers of person with mental

Table 3 - Knowledge regarding disability certificate uses:

\begin{tabular}{|c|c|c|c|c|}
\hline \multirow{2}{*}{ S. } & \multirow{2}{*}{ Domain } & \multicolumn{3}{|c|}{$\mathrm{N}=67$} \\
\hline & & \multicolumn{2}{|c|}{$\mathbf{N}$} & $\%$ \\
\hline \multirow[t]{2}{*}{1.} & \multirow{2}{*}{$\begin{array}{l}\text { Do you know about the legal right of } \\
\text { mentally disabled persons }\end{array}$} & Yes & 14 & 20.89 \\
\hline & & No & 53 & 79.11 \\
\hline \multirow[t]{2}{*}{2.} & \multirow{2}{*}{$\begin{array}{l}\text { Do you know about social security of } \\
\text { mentally disabled person? }\end{array}$} & Yes & 00 & 00 \\
\hline & & No & 67 & 100 \\
\hline \multirow[t]{2}{*}{3.} & \multirow{2}{*}{$\begin{array}{l}\text { Do you know about health care facility } \\
\text { for the mental disabled person? }\end{array}$} & Yes & 00 & 00 \\
\hline & & No & 67 & 67 \\
\hline \multirow[t]{2}{*}{4.} & \multirow{2}{*}{$\begin{array}{l}\text { Do you know that for mental disabled } \\
\text { have facilities like scholarship, pension } \\
\text { and unemployment allowance? }\end{array}$} & Yes & 44 & 65.67 \\
\hline & & No & 23 & 34.33 \\
\hline \multirow[t]{2}{*}{5.} & \multirow{2}{*}{$\begin{array}{l}\text { Do you know that the mentally disabled } \\
\text { havesomereservation undergovernment } \\
\text { employment and private employment? }\end{array}$} & Yes & 17 & 25.37 \\
\hline & & No & 50 & 74.63 \\
\hline \multirow[t]{2}{*}{6.} & \multirow{2}{*}{$\begin{array}{l}\text { Do you know that the insurance facility } \\
\text { available for men tally disabled person? }\end{array}$} & Yes & 00 & 00 \\
\hline & & No & 7 & 100 \\
\hline \multirow[t]{2}{*}{7.} & \multirow{2}{*}{$\begin{array}{l}\text { Do you know about rehabilitation } \\
\text { provision for mentally disabled person? }\end{array}$} & Yes & 00 & 00 \\
\hline & & No & 7 & 100 \\
\hline \multirow[t]{2}{*}{8.} & \multirow{2}{*}{$\begin{array}{l}\text { Do you know reservation for that land } \\
\text { allotment to mentally abled person? }\end{array}$} & Yes & 00 & 00 \\
\hline & & No & 67 & 100 \\
\hline \multirow[t]{2}{*}{9.} & \multirow{2}{*}{$\begin{array}{l}\text { Do you know the reservation facilities } \\
\text { available for mentally disabled person } \\
\text { in any developmental scheme run by } \\
\text { central and state government? }\end{array}$} & Yes & 00 & 00 \\
\hline & & No & 67 & 100 \\
\hline \multirow[t]{2}{*}{10.} & \multirow{2}{*}{$\begin{array}{l}\text { Do you know that the government } \\
\text { provide skills development program for } \\
\text { mentally disabled? }\end{array}$} & Yes & 00 & 00 \\
\hline & & No & 67 & 100 \\
\hline \multirow[t]{2}{*}{11.} & \multirow{2}{*}{$\begin{array}{l}\text { Do you know they would get loans at } \\
\text { concession interest rate? }\end{array}$} & Yes & 21 & 31.34 \\
\hline & & No & 46 & 68.66 \\
\hline \multirow[t]{2}{*}{12.} & \multirow{2}{*}{$\begin{array}{l}\text { Do you government provided market- } \\
\text { ing of goods made by mentally disabled } \\
\text { person? }\end{array}$} & Yes & 00 & 00 \\
\hline & & No & 67 & 100 \\
\hline \multirow[t]{2}{*}{13.} & \multirow{2}{*}{$\begin{array}{l}\text { Do you know that the person get } \\
\text { concession in railways in travel } \\
\text { allowance? }\end{array}$} & Yes & 61 & 91.04 \\
\hline & & No & 6 & 8.96 \\
\hline
\end{tabular}

illness have knowledge regarding government facilities in different areas, only $20.89 \%$ care givers know about legal right of patients and $65.67 \%$ caregivers know about pension scheme. Only $25.37 \%$ caregivers know about reservation under government and private employment. 91.4\% caregivers know about concession given by railway for travel and only $31.34 \%$ caregivers know facilities related to loan/interest rate. Findings indicated that caregivers of the persons with mental illness were not aware about health care facility, social security, insurance facility, rehabilitation provision, reservation for that land allotment, reservation facilities available for developmental scheme, skills development program, marketing facilities.

\section{DISCUSSION}

In our study mean age of patients was $35.46 \pm 12.75$ and duration of illness was $6.98 \pm 4.25$. Majority of the patients belonged to rural background and $36.66 \%$ caregivers were educated up to primary level. Most of the patient's family income was 5000 to 10000. In our study $88.75 \%$ caregivers of persons with mental illness do not know that mental illness comes under the disability and only $47.5 \%$ caregivers know that certificate is provided to the persons with mental illness. $66.88 \%$ caregivers do not know that where they can get the certificate and $86.88 \%$ caregivers do not know about criteria for such certificate. Only $11.25 \%$ caregivers got certificate for their patients and only $41.88 \%$ caregivers have knowledge about government facility for mental disability. According to Kashyap et al $99.4 \%$ of persons with disability from rural area of Karnatka had not availed any benefits other than disability pension which show poor 
awareness about these benefits. The researcher suggest the exclusive education and awareness program and disability awareness camp in outreach area. ${ }^{[15]}$

In our study caregivers of person with mental illness have knowledge regarding government facilities in different areas, only $20.89 \%$ caregivers know about legal right, $65.67 \%$ caregivers know about pension scheme, $25.37 \%$ caregiver know about reservation under government and private employment of patients. Majority of the caregivers i.e., $91.4 \%$ caregivers know about concession given by railway for travel and only $31.34 \%$ caregiver know facilities related to loan/interest rate. No one caregiver was aware about health care facility, social security, insurance facility, rehabilitation provision, reservation for that land allotment, reservation facilities available for developmental scheme, skills development program, marketing facilities. According to Sarkar and Rout (2012) about $41 \%$ of the participants had no idea about the utility of a disability certificate. Among those who were aware, it was reported that the certificate was most often used to obtain transport benefits $(30.1 \%)$. The other significant usage included vocational benefits $(13.9 \%)$, financial benefits $(10.4 \%)$, medical benefits $(8.4 \%)$ and educational benefits $(6.2 \%) \cdot{ }^{[16]}$

This finding may be attributed to the fact that the sample for the current study has been derived from a rural population in Ranchi where there is a stark lack in public knowledge and awareness of the different facilities provided by the government and also because of the dearth of awareness programs conducted in these areas. Also in addition the literacy rate over here is much lower which also might be a potent reason behind the lack of knowledge regarding such matters. Moreover, those who know of such provisions by the government lack in their knowledge of where to get it from or even if they reach the desired institution that provides such certificate the process may be clogged by bureaucratic procedures prevalent in such institutions. Another potent reason may be the fact that the people may only be aware of having Rail Passes while not knowing of the disability certificates altogether. Again at times due to physical constraints like lack of transport facility, geographical locations can contribute to the lack of knowledge and lack of resources available to the individual to procure such certificate. Also the public sectors wherefrom they can get the facilities are seldom informed about these or are interested to help these due to bureaucratic backlogs.

\section{CONCLUSION}

Present study concludes that majority of the caregivers of the persons with mental illness are not aware of the disability certificate and its uses and benefits which provided by the government of India. However majority of the caregivers are aware of the railway passes benefits. So, considering the lack of awareness in the public for which more disability certification awareness programs are needed with regards to uses and benefits at the community level.

\section{REFERENCE}

1. Morris J. Impairment and disability: constructing an ethics of care that promotes human rights. Hypatia. 2001; 16(4) : $1-16$.

2. Gururaj G, Varghese M, Benegal V, Rao GN, Pathak K, Singh LK, et al. National Mental Health Survey of India 2015-2016. Bengaluru: National Institute of Mental Health and Neuro Sciences, NIMHANS Publication; 2016.

3. Charlson FJ, Baxter AJ, Cheng HG, Shidhaye R, Whiteford HA. The burden of mental, neurological, and substance use disorders in China and India: A systematic analysis of community representative epidemiological studies. Lancet 2016; $388: 376-89$.

4. Whiteford HA, Degenhardt L, Rehm J, Baxter AJ, Ferrari AJ, Erskine HE, et al. Global burden of disease attributable to mental and substance use disorders: Findings from the Global Burden of Disease Study 2010. Lancet 2013; 382: 1575-86.

5. Mohan I, Tandon R, Kalra H, TrivediJK. Disability assessment in mental illnesses using Indian Disability Evaluation Assessment Scale (IDEAS). Indian J Med Res 2005; 121 : 759-63.

6. Mykletun A, Overland S, Dahl AA, Krokstad S, Bjerkeset O, Glozier N, et al. A population-based cohort study of the effect of common mental disorders on disability pension awards. Am J Psychiatry 2006; 163 : 1412-8. 


\section{Awareness of disability certificate among caregivers}

7. Buist-Bouwman MA, De Graaf R, Vollebergh WA, Alonso J, Bruffaerts R, Ormel J; ESEMeD/MHEDEA Investigators. Functional disability of mental disorders and comparison with physical disorders: A study among the general population of six European countries. ActaPsychiatrScand 2006; $113:$ 492-500.

8. The Rights of Persons with Disabilities Act, 2016, Gazette of India (Extra-Ordinary); 28 December, 2016

9. The Persons with Disabilities (Equal Opportunities, Protection of Rights and Full Participation) Act; 1995.

10. Ministry of Social Justice and Empowerment. Notification, 2018, Gazette of India (Extra-Ordinary) Department of Empowerment of Persons with Disabilities (Divyangjan) 2018.

11. Murthy RS. National mental health survey of India 20152016. Indian journal of psychiatry. 2017 Jan; 59(1):21.
12. Narayan CL, John T. The Rights of Persons with Disabilities Act, 2016: Does it address the needs of the persons with mental illness and their families. Indian journal of psychiatry. 2017 Jan; 59 (1):17.

13. Kala A. Time to face new realities; mental health care bill2013. Indian J Psychiatry 2013; $55:$ 216-9.

14. Mishra NN, Parker LS, Nimgaonkar VL, Deshpande SN. Disability certificates in India: a challenge to health privacy. Indian journal of medical ethics. 2012 Jan; 9(1) : 43.

15. Kashyap K, Thunga R, Rao Ak, Balamurali Np. Trends to utilization of government disability benefits among chronic mentally ill. Indian J Psychiatry 2012; 54(1) : 54-58.

16. Sarkar M, Rout N. Awareness about benefits of a disability certificate among persons with hearing impairment in Kolkata, India. Disability, CBR \& Inclusive Development. 2012 May 31; 23(1) : 100-1. 